Annals of Warsaw University of Life Sciences - SGGW

Land Reclamation No 38, 2007: 41-47

(Ann. Warsaw Univ. of Life Sci. - SGGW, Land Reclam. 38, 2007)

\title{
Some maintenance problems of the drip irrigation in Poland
}

\section{JERZY JEZNACH}

Department of Environmental Improvement

Warsaw University of Life Sciences - SGGW

\begin{abstract}
Some maintenance problems of the drip irrigation in Poland. Drip irrigation system will play in the future a significant role in fulfilling the requirements of intensive, energysaving agricultural production. Total area under microirrigation in Poland can be now estimated as about 10000 hectares. Drip irrigation is applied mainly in orchards, vegetable farms and greenhouses. The investigations on drip irrigation have shown a high influence of the agricultural conditions on the operation and reliability and productivity effects of the irrigation system. Paper present the investigation of the operation of drip irrigation systems in various regions of Poland. The analysis is based on the results of the manufacture coefficient of variation $\mathrm{Cv}$, emitter exponent $\mathrm{n}$, uniformity coefficient and detailed observation of the work time, breaks, failures and any other damages to the system.
\end{abstract}

Key words: drip irrigation, emitter exponent, uniformity, coefficient of variation, operation, reliability.

\section{INTRODUCTION}

The climatic data for temperature, radiation, humidity and rainfall from individual years in Poland demonstrate large deviation from the average long term values. There are several reasons for these variations in climatic conditions.

Overall hydrological conditions in Poland are not favourable for agriculture. The quantity of water in Poland per capita is one of the lowest in Europe. Summer rains frequently result in flooding and/or crop damage, while at the same time, almost every year, there are some periods of drought (Somorowski, 1993).

The soils in Poland are mainly of glacier origin and show a significant special variability. Approximately 50\% of soils can be classified as sandy with low water holding capacity.

With limited water quantity, drip irrigation, with its potentially high efficiency, often presents the only viable alternative for supplying necessary water. This is especially true for fruit and vegetable farms, nurseries, greenhouses and various production systems under plastic tunnels (Jeznach, Pierzgalski, Haman, 1995).

It is estimated that if the present trend prevails, the land under microirrigation will have occupied the area of 10000 hectares.

Within twenty years of application of drip irrigation system, a large technical and technological progress, in particular with regard to design principles with computer support, quality of produced equipment and irrigation control technology for fertilization throughout the irrigation system has been achieved. At present, the opinion is held that the problems connected with the operation of the drip irrigation systems, are the main obstacles which restrain the utilization of their potential advantages. 
The reliability of drip irrigation systems, i.e. their capability of supplying the required amount of water of appropriate quality to plants, provided the uniformity of irrigation, at any time, under given operating conditions, can be measured. Such measurable characteristics of reliability of the system is the probability of certain events (Jeznach, 1998).

\section{METHODS AND INVESTIGATION SITES}

The investigation of the operation and reliability of drip irrigation systems has been conducted on sites in various regions of Poland and in the University laboratory. The analysis are based on the laboratory results of the manufacture coefficient of variation $\mathrm{Cv}$ and emitter exponent n (Jeznach, 1996, Polish Norm PN-ISO 1997), uniformity coefficient of emitter distribution and detailed observation of the work time, breaks, failures and any other damages to the system was measured on the experimental fields.

According to this norm the manufacture coefficient of variation $\mathrm{CV}$ was determined from the relationships:

$$
\mathrm{Cv}=\frac{\mathrm{S}}{\mathrm{q}_{\mathrm{av}}} \cdot 100 \%
$$

where:

$\mathrm{S}$ - standard deviation,

$\mathrm{q}_{\mathrm{av}}$ - average emitter discharge.

Moreover, the relationships between water discharge from emitter $\mathrm{q}$ and the pressure $\mathrm{H}$ in the shape: $\mathrm{q}=\mathrm{a} \cdot \mathrm{H}^{\mathrm{n}}$

where:

$q$ - emitter discharge,

$\mathrm{H}$ - water pressure,

a - empirical coefficient,

$\mathrm{n}$ - emitter exponent.

The probability of reliable, defect-free operation of the system $R(t)$ in the time $t$ was determined on the basis of the above indices. The $\lambda$ function of the intensity of defect should be adopted. The reliability of the drip irrigation systems has been defined by the exponential equation:

$\mathrm{R}(\mathrm{t})=\exp (-\lambda \cdot \mathrm{t})$

where:

$\mathrm{R}(\mathrm{t})$ - reliability of the drip irrigation systems, defect-free operation of the system,

$\lambda$ - function of the intensity of defect, $\mathrm{t}$ - time [hour].

\section{RESULTS AND DISCUSSION}

Changes of the manufacture coefficient of variation $\mathrm{Cv}$, and emitter's exponent $n$ presented as examples in the Figures 1 and 2.

The results of investigations show on systematic diminished of the technical parameters of emitters in exploitation.

The coefficient of variation $\mathrm{Cv}$ increase about $2 \%$ in two years after operation and about $5 \%$ in third fourth years. Value $\mathrm{Cv}$ after three years it increasing $10 \%$ on some objects. This concerns both the capillary and compensation emitters. Installation of the II degree filters reduced the increases of coefficient $\mathrm{Cv}$. The flushing the installation under higher water pressure, reduced the increases of value $\mathrm{Cv}$. 


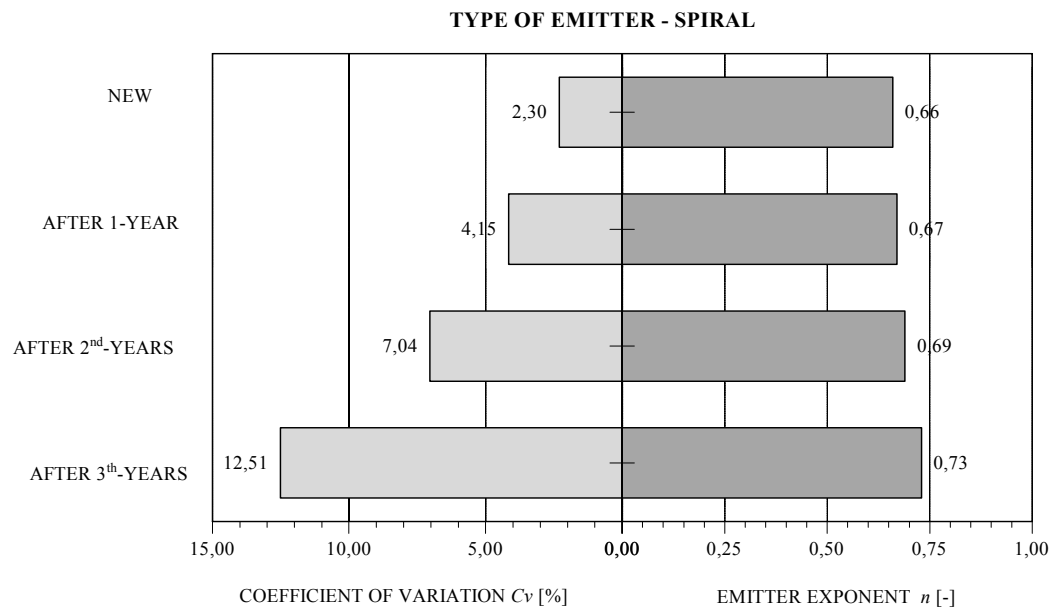

FIGURE 1. Changes of coefficient of variation $\mathrm{Cv}$ and emitter exponent $\mathrm{n}$ during operation on field site

TYPE OF EMITTERS-SPIRAL AND NETAFIM

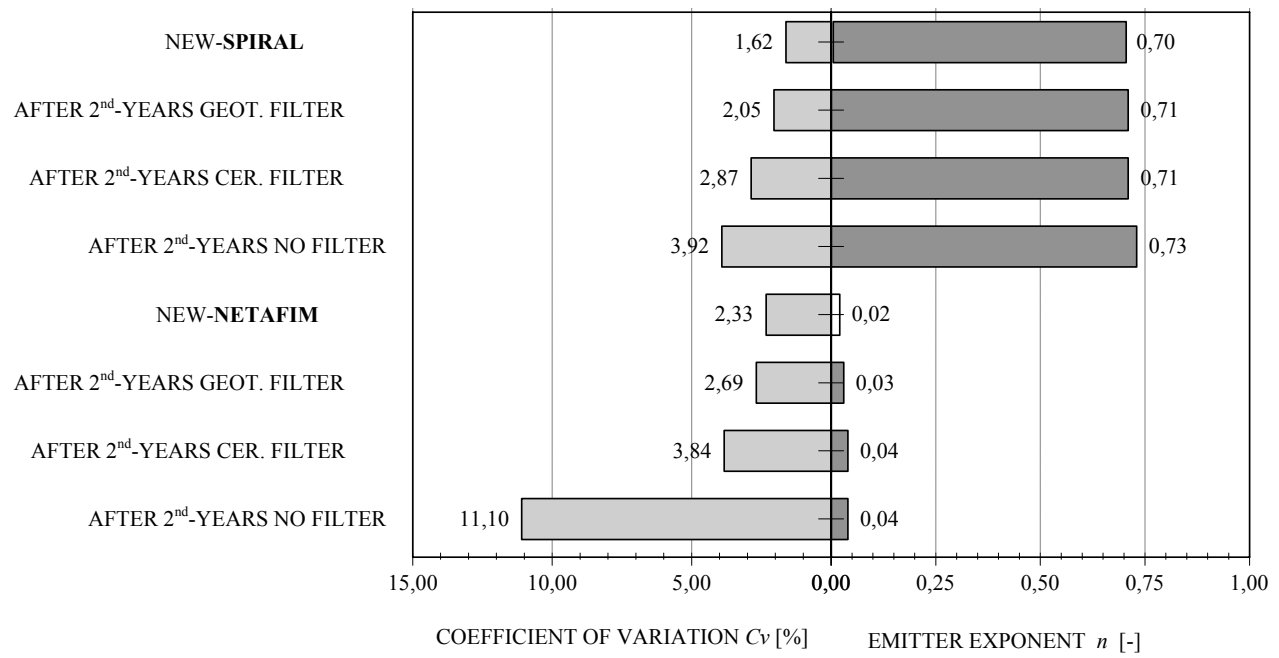

FIGURE 2. Changes of coefficient of variation $\mathrm{Cv}$ and emitter exponent $\mathrm{n}$ during operation on field site

The obtained values of emitter The application uniformity is classified exponent was observed that the nincrease as high if $\mathrm{Cu}>90 \%$. If $\mathrm{Cu}<80 \%$ the about $1.1-1.5 \%$ annually.

The evaluation of system performance is done by field evaluation of the system application uniformity. In Poland, the reasons for low uniformity should be determined and corrected. If has been determined that the uniformity of the most commonly used method is the system will decrease with the age of the Christiansen Uniformity Coefficient $(\mathrm{Cu})$. the problem and the rate of degradation 
depend of many factors, such as irrigation water quality, filtration, and the type of emitters used. Tables 1, 2 and 3 presents a decrease in emitter's discharge and uniformity in Experimental Plot at Warsaw Agricultural University. There was no significant difference in the system where fertilisers were injected as compared to the system without such injections.

The results of several experiments demonstrated that the uniformity of water application was decreasing anywhere from $1 \%$ to $12 \%$ annually depending on irrigation water quality, water treatment, and the type and concentration of fertilisers used in fertigation (Jeznach, 1996). Generally, the value of $\mathrm{Cu}$ was below $90 \%$ after first three years in the field. An improvement in system performance was obtained by using secondary filters, periodic flushing of lines using higher water pressure than the design operating pressure, and maintaining the $\mathrm{pH}$ of the water between 5.5 and 6.0 .

A careful analysis of the reliability and defects of the systems helped determine the main reliability parameters of the drip irrigation systems under study. Figures

TABLE 1. Changes of emitter's discharge $\Delta q$ and coefficient's uniformity $\mathrm{Cu}$ in different time of operation

\begin{tabular}{|l|c|c|c|c|c|c|c|}
\hline \multirow{2}{*}{ Land use } & \multicolumn{5}{|c|}{$\Delta \mathrm{q}[\%]$} & \multicolumn{4}{c|}{$\mathrm{Cu}[\%]$} \\
\cline { 2 - 7 } & \multicolumn{6}{|c|}{ Time of operation } \\
\cline { 2 - 7 } & 1 year & 3 years & 5 years & 1 year & 3 years & 5 years \\
\hline Orchards & 4.3 & 6.7 & 9,2 & 95.30 & 90.13 & 87.20 \\
Vegetables & 5.6 & 7.1 & 10,4 & 97.83 & 93.26 & 91.81 \\
Greenhouses-with soil & 4.2 & 7.0 & 11,6 & 96.45 & 92.37 & 88.14 \\
Greenhouses-without soil & 6.8 & 9.2 & 14,4 & 94.38 & 90.73 & 85.44 \\
\hline
\end{tabular}

TABLE 2. Changes of emitter's discharge $\Delta \mathrm{q}$ and coefficient's uniformity $\mathrm{Cu}$ after three years of operation in different land use

\begin{tabular}{|l|c|c|c|c|}
\hline \multirow{2}{*}{ Land use } & \multicolumn{2}{|c|}{$\Delta \mathrm{q}[\%]$} & \multicolumn{2}{c|}{$\mathrm{Cu}[\%]$} \\
\cline { 2 - 5 } & irrigation & fertigation & irrigation & fertigation \\
\hline Orchards & 6.9 & 8.2 & 92.18 & 87.46 \\
Vegetables & 7.3 & 9.8 & 95.61 & 91.49 \\
Greenhouses-with soil & 7.4 & 11.6 & 94.73 & 89.92 \\
Greenhouses-without soil & 9.2 & 12.8 & 93.56 & 88.86 \\
\hline
\end{tabular}

TABLE 3. Changes of emitter's discharge $\Delta \mathrm{q}$ and coefficient's uniformity $\mathrm{Cu}$ after three years of operation in different type of emitters (emitter exponent $\mathrm{n}$ )

\begin{tabular}{|l|c|c|c|c|c|c|}
\hline \multirow{2}{*}{ Land use } & \multicolumn{3}{|c|}{$\Delta \mathrm{q}[\%]$} & \multicolumn{3}{c|}{$\mathrm{Cu}[\%]$} \\
\cline { 2 - 7 } & $\mathrm{n}=0.02$ & $\mathrm{n}=0.72$ & $\mathrm{n}=0.80$ & $\mathrm{n}=0.02$ & $\mathrm{n}=0.72$ & $\mathrm{n}=0.80$ \\
\hline Orchards & 4.5 & 6.7 & 7.6 & 94.14 & 91.02 & 90.18 \\
Vegetables & 5.2 & 7.1 & 9.2 & 96.25 & 93.18 & 91.39 \\
Greenhouses-with soil & 4.2 & 7.0 & 10.8 & 95.23 & 93.14 & 91.07 \\
Greenhouses-without soil & 6.8 & 9.2 & 13.0 & 93.34 & 91.28 & 89.83 \\
\hline
\end{tabular}


3 and 4 show $\mathrm{R}(\mathrm{t})$ curves as examples calculated for the studied systems and given environmental conditions. Figure 5 shows $\mathrm{R}(\mathrm{t})$ curves as examples calculated for the sprinkler systems in vegetables.

The evaluations of different irrigation systems with different types of equipment suggest that the proposed reliability indices can be used to compare the performance of systems under different environmental conditions and across a large variation of irrigation installations. The reliability criterion allows a full evaluation of the operation of drip irrigation systems because it covers the entire period of the system operation (Jeznach, 1998).

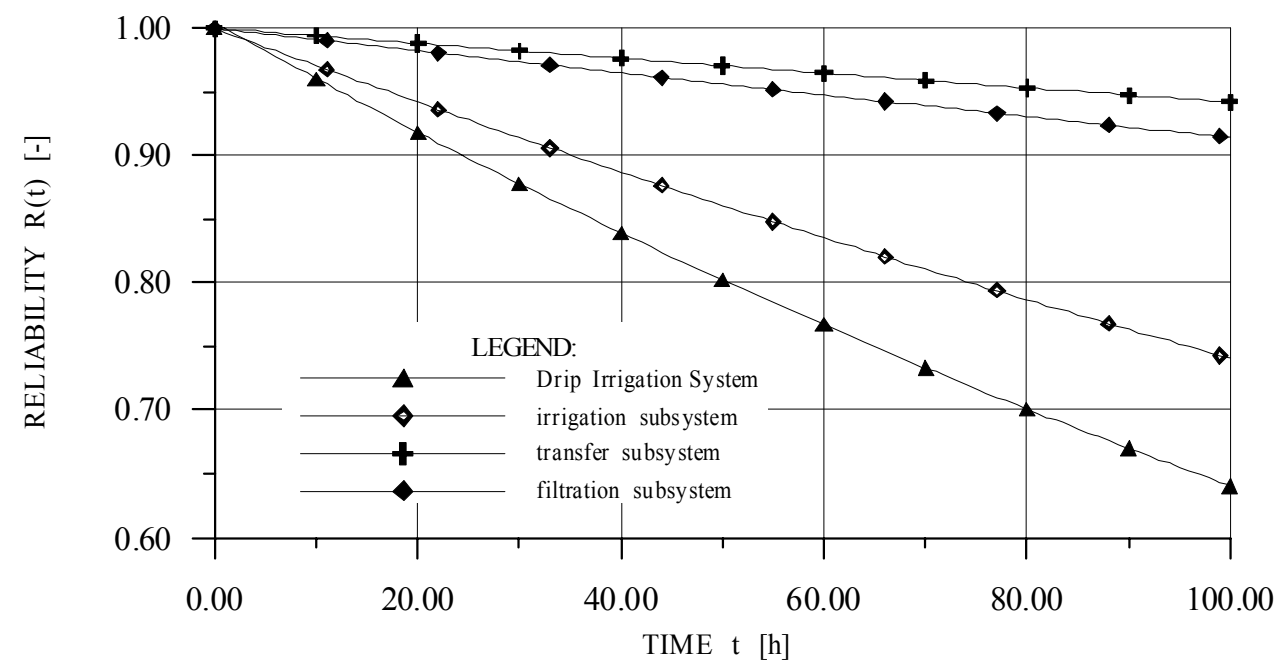

FIGURE 3. Reliability of the drip irrigation system in orchard

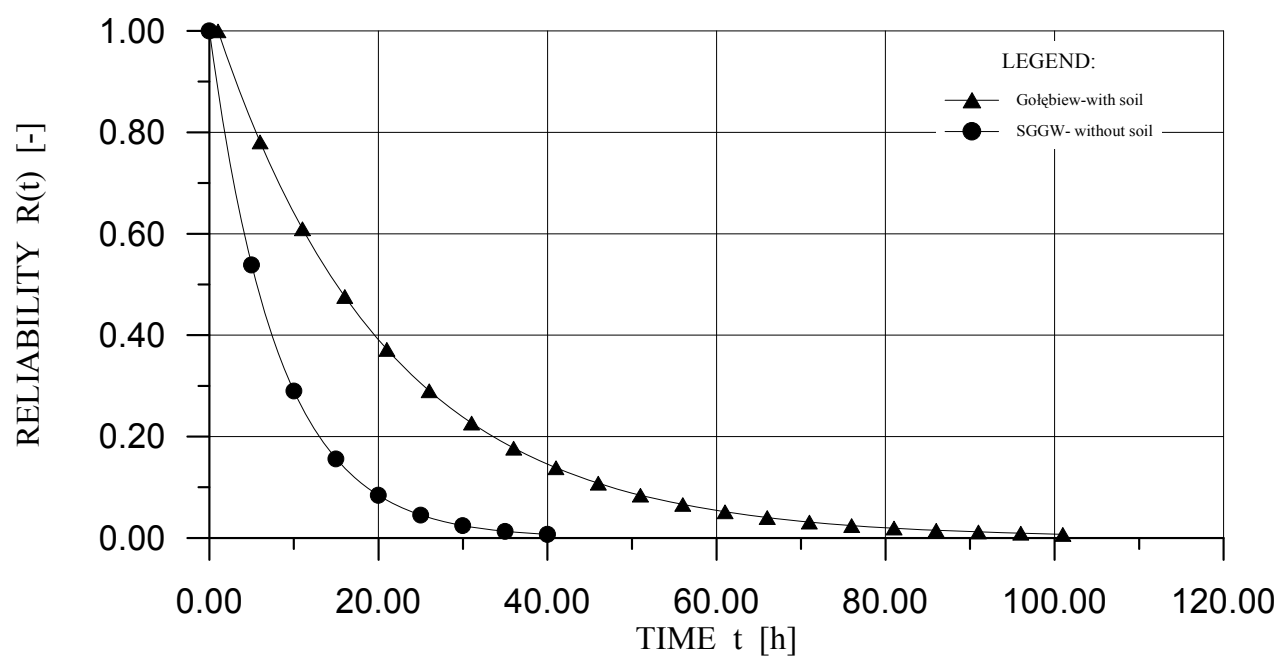

FIGURE 4. Reliability of the drip irrigation system in greenhouses 


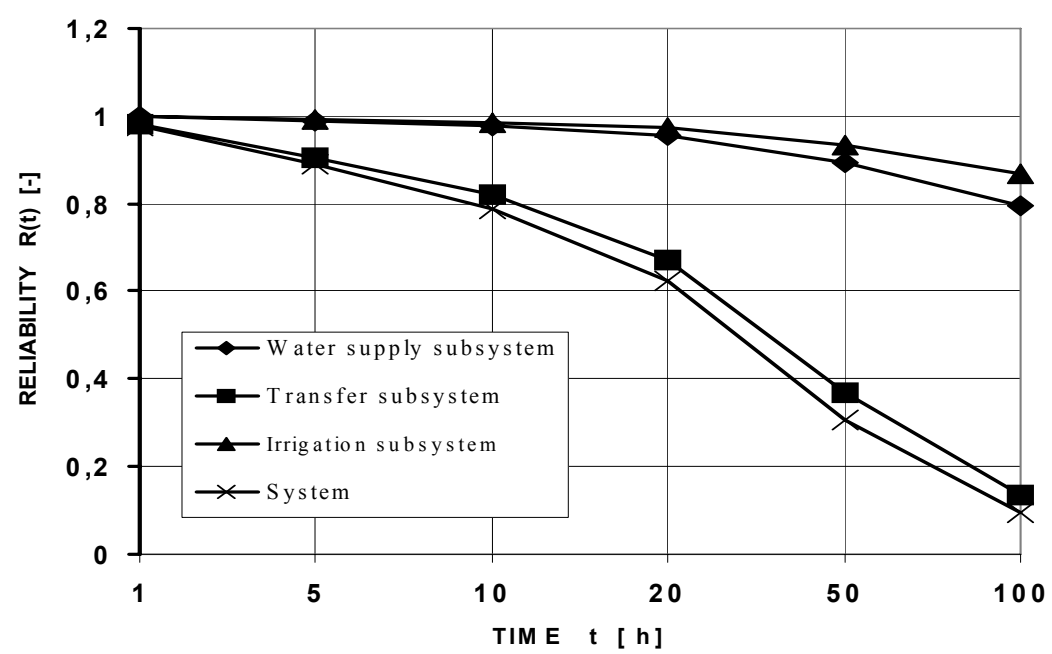

FIGURE 5. Reliability of the sprinkler irrigation system in vegetables

The reliability criterion makes it also possible to carry out a detailed analysis of the impact of the individual subsystems on the operation of the entire system and to determine the most defect-susceptible sections of the system. This analysis provides grounds for the adoption of correct design solutions and operation procedures.

Under Polish conditions the drip irrigation systems, often built with a do-ityourself method, usually meet the adopted reliability criteria. Defects were first of all caused by wrong design solutions, wrong selection of equipment, and failure to follow operation instructions.

\section{CONCLUSIONS}

1. The supplemental character of irrigation in Poland, low quality of water resources and significant variability of equipment used in drip irrigation systems result in large variability of system performance.
The evaluation of system performance is done by field evaluation of the system application uniformity.

2. The results of investigations show on systematic diminished of the technical parameters of emitters in exploitation.

3. The coefficient of variation $\mathrm{Cv}$ increase about $2 \%$ in two years after operation and about $5 \%$ in third - fourth years. Value $\mathrm{Cv}$ after three years it increasing $10 \%$ on some objects. This concerns both the capillary and compensation emitters.

4. The obtained values of emitter exponent was observed that the $\mathrm{n}$ increase about $1.1-1.5 \%$ annually.

5. The results of several experiments demonstrated that the uniformity of water application was decreasing anywhere from $1 \%$ to $12 \%$ annually. Generally, the value of $\mathrm{Cu}$ was below $90 \%$ after first three years in the field.

6. The reliability criterion allows a full evaluation of the operation of 
drip irrigation systems because it covers the entire period of the system operation. The to-date used homogeneity criterion only permits the evaluation of the system when it runs at full efficiency without considering defects and time when it is out of order.

7. Under Polish conditions the drip irrigation systems, often built with a do-it-yourself method, usually meet the adopted reliability criteria. Defects were first of all caused by wrong design solutions, wrong selection of equipment, and failure to follow operation instructions.

\section{REFERENCES}

JEZNACH J., PIERZGALSKI E., HAMAN D. 1995: Review of Development of Microirrigation in Poland. Proceed. of the Fifth International Microirrigation Congress. Orlando, Florida, USA; 336-340 .

JEZNACH J. 1996: The analysis of operation of drip irrigation systems under different environmental conditions. Warsaw Agricultural University, SGGW, Warsaw. Scientific Discussion Papers, pp. 177 (in Polish).

JEZNACH J. 1998: Reliability of the Drip Irrigation Systems under Different Operation Conditions in Poland. Agricultural Water Management. Elsevier; Vol. 35, 261-167.

POLISH NORM PN - ISO 9260 (1997): Agricultural irrigation equipment Emitters - Specification and test method (in Polish).

SOMOROWSKI C. (Ed.) 1993: Contemporary land improvement problems. SGGW, Warsaw, p. 256 (in Polish).
Streszczenie: Problemy eksploatacyjne systemów nawodnień kroplowych $w$ Polsce. O celowości stosowania nawodnień kroplowych w Polsce decydują przesłanki środowiskowe (klimat, gleby), ekologiczne (zasoby wodne, skażenie roślin, gleb i wód powierzchniowych i gruntowych) oraz społeczno-ekonomiczne. Według danych szacunkowych w 2006 r. systemami tymi nawadniano około 10000 ha sadów, warzyw i upraw pod osłonami. Pomimo znaczącego postępu we wdrażaniu tych systemów wiele zagadnień wymaga pilnego rozwiązania. Przedstawione w pracy wyniki badań wskazują na systematyczne pogarszanie się parametrów technicznych emiterów w kolejnych latach eksploatacji. Intensywność tego procesu zależała od warunków środowiskowych obiektu, głównie stopnia uzdatniania wody, podawania nawozów poprzez system, wyposażenia systemu (dodatkowe filtry II stopnia) i stosowanych zabiegów konserwacyjnych (płukanie). Współczynnik zmienności Cv zwiększał się średnio o około $2 \%$ w pierwszych dwóch latach po założeniu instalacji i ok. $5 \% \mathrm{w}$ trzecim i w czwartym roku eksploatacji. Dotyczy to zarówno emiterów kapilarnych, jak i z kompensacją ciśnienia. Zainstalowanie filtrów II stopnia na poszczególnych kwaterach lub przewodach nawadniających zdecydowanie zmniejszało przyrosty współczynnika zmienności Cv i wydłużało okres poprawnej pracy emiterów. Również płukanie instalacji, pod wyższym ciśnieniem wody, znacznie zmniejszało przyrosty wartości $C_{\mathrm{v}}$. Zaobserwowano także podwyższenie wartości wykładnika potęgowego n o około 1,1-1,5\% rocznie. Kryterium niezawodności umożliwia przeprowadzenie szczegółowej analizy wpływu poszczególnych podsystemów na funkcjonowanie całego systemu. W warunkach polskich systemy nawodnień kroplowych, spelniają przyjęte kryteria niezawodności.

\section{MS. received November 2007}

\section{Author's address:}

Department of Environmental Improvement Warsaw University of Life Sciences - SGGW 02-776 Warszawa, ul. Nowoursynowska 159. Poland e-mail: jerzy_jeznach@sggw.pl 